\title{
Evaluation of Elite Clones of Banana on Yield and Yield Attributing Parameters in Coastal Zones of Odisha
}

\author{
Kiran Patnaik* and Pratichee Mohapatra \\ Department of Fruit Science and Horticulture Technology, O.U.A.T, \\ Bhubaneshwar, 751003, India \\ *Corresponding author
}

\section{Keywords}

Cooking bananas, Dessert bananas, Yield, Yield attributing parameters

\section{Article Info}

Accepted: 10 November 2019 Available Online: 10 December 2019

\section{A B S T R A C T}

Eleven banana genotypes viz. Champa (AAB), Budubale (PisangAwak), BCB-3 (AAB), H-531 (Poovan x PisangLilin), BCB-1 (AAB), KBS-8 (Dwarf Cavendish-AAA), Bantal (ABB), BCB-2 (ABB), KovurBontha (Monthan-ABB), ManjeriNendran II (AAB) and NRCB-8 (ABB) were evaluated for the yield and yield attributing parameters like the bunch weight $(\mathrm{kg})$, bunch length $(\mathrm{cm})$, bunch girth $(\mathrm{cm})$, number of hands, total number of fingers, finger length $(\mathrm{cm})$, finger circumference $(\mathrm{cm})$, finger weight $(\mathrm{g})$. From the results it was found that, among the dessert types the performance of BCB-3 was better as compared to other genotypes with regards to bunch weight (14.77 kg), number of hands (12.87), number of fingers (148.91), finger length $(21.07 \mathrm{~cm})$, finger weight $(101.21 \mathrm{~g})$ and yield (31.7 t/ha). The genotype BCB-2 among the culinary types was found to be superior as compared to other genotypes with regards to bunch weight $(16.52 \mathrm{~kg}$ ), number of hands (12.80), number of fingers (125.05), finger length $(19.53 \mathrm{~cm})$, finger weight $(137.48 \mathrm{~g})$ and yield $(35.18 \mathrm{t} / \mathrm{ha})$.

\section{Introduction}

Banana is a tropical fruit grown in over 122 countries worldwide. Globally, dessert bananas (Musa spp., AA, $\mathrm{AB}$ and AAA genome) and cooking banana (AAB), constitute fourth most important commodity after rice, wheat and maize. Banana (Musa spp.) belongs to the family Musaceae is one of the most important fruit crops, especially of the tropics. In India banana is cultivated in an area of 841.2 thousand ha with a production of 29134.8thousand MT. (National Horticulture Database-2015). In Odisha banana cultivation has an area of 24.56 thousand ha, a production of 466.9 thousand MT and a productivity of $20.18 \mathrm{MT} / \mathrm{ha}$. (Directorate of Horticulture, Govt. of Odisha, 2017-18). The state has 
potentiality for both dessert and culinary banana varieties. Under dessert varieties, Champa, Patakpura, Dwarf cavendish, Robusta, Srimanta, Grand Naine are grown successfully in commercial scale. There are several hill bananas grown by tribals along the hill streams. The varieties are Muguni, Bukuphata, Podasingha, Birupakhi etc. Under culinary types, Bantal, GajaBantal, Paunshia Bantal, Mendhi Bantal etc. are grown. The choice of suitable variety is of paramount importance for successful commercial cultivation of banana. Thus, the experiment was done with the objective of recognizing a suitable cultivar for coastal pockets of Odisha for commercial cultivation

\section{Materials and Methods}

The experiment was carried out at Horticultural Research Station (HRS), Orissa University of Agriculture and Technology (O.U.A.T), Bhubaneswar, Odisha during the year 2014-15. The experiment design was randomized block design with eleven banana genotypes as treatments which were replicated thrice. Eleven banana genotypes viz. Champa $(\mathrm{AAB})$, Budubale (PisangAwak), BCB-3 (AAB), H-531 (Poovan X PisangLilin), BCB1 (AAB), KBS-8 (Dwarf Cavendish -AAA), Bantal (ABB), BCB-2 (ABB), KovurBontha (Monthan-ABB), ManjeriNendran II (AAB) and NRCB-8 (ABB) were the treatments namely $\mathrm{T}_{1}$ to $\mathrm{T}_{11}$. These were evaluated for the yield attributing parameters in the investigation entitled "Evaluation of elite clones of banana in coastal zones of Odisha".

Yield and yield attributing parameters like bunch weight, number of hands in a bunch, number of fingers in a bunch, finger weight, finger length and finger circumference were recorded from ten plants of each treatment and their average was worked out. The under developed hands were excluded. Undeveloped fingers close to male flower were not taken into account. The stalk of the finger was not taken into account, to get the effective length of fingers. The measurement of finger circumference was taken from the middle of the finger.

\section{Results and Discussion}

Bunch weight ranged from $9.47 \mathrm{~kg}$ to $16.52 \mathrm{~kg}$ (Table 1). Maximum bunch weight was observed in BCB-3 (14.77 kg) among dessert types and BCB-2 $(16.52 \mathrm{~kg})$ among culinary banana whereas minimum bunch weight was recorded in $\mathrm{H}-531(9.71 \mathrm{~kg})$ among dessert banana and KovurBontha $(9.47 \mathrm{~kg})$ among culinary types. W.r.t bunch length a range of $63.63 \mathrm{~cm}$ to $92.67 \mathrm{~cm}$ was recorded (Table 1) where maximum bunch length was recorded in BCB-3 $(92.67 \mathrm{~cm})$, a dessert type whereas minimum was observed in ManjeriNendran II $(63.63 \mathrm{~cm})$, a culinary type. Similarly, Bunch girth ranged from $60.10 \mathrm{~cm}$ to $80.73 \mathrm{~cm}$ (Table 1) in which maximum was recorded in Champa (a dessert type, $80.73 \mathrm{~cm}$ ) whereas minimum was observed in ManjeriNendran II (a culinary type, $60.10 \mathrm{~cm}$ ). A reference to Table 1 shows that a wide range of variation from 5.83 to 12.87 was noticed with respect to number of hands per bunch. Number of hands per bunch was maximum in genotype BCB-3 (12.87) which was at par with NRCB-8 (12.80). Minimum number of hands per bunch was observed in ManjeriNendran II (5.83).A wide range of variation from 58.24 to 148.91 was observed with respect to number of fingers per bunch (Table 1). Maximum number of fingers per bunch were recorded in BCB-3 (148.91) followed by NRCB-8 (146.08) and Champa (141.42). Minimum number of fingers was observed in ManjeriNendran II (58.24). A significant range of variation of $13.40 \mathrm{~cm}$ to $26.10 \mathrm{~cm}$ was also observed with regard to finger length (Table 1). 
Table.1 Yield and yield attributing characters of 11 genotypes of Banana

\begin{tabular}{|c|c|c|c|c|c|c|c|c|c|}
\hline $\begin{array}{l}\text { Characters } \\
\text { Genotypes }\end{array}$ & $\begin{array}{c}\text { Bunch } \\
\text { weight } \\
\text { (kg) }\end{array}$ & $\begin{array}{c}\text { Bunch } \\
\text { length } \\
(\mathrm{cm})\end{array}$ & $\begin{array}{l}\text { Bunch } \\
\text { girth } \\
\text { (cm) }\end{array}$ & $\begin{array}{c}\text { Number } \\
\text { of hands } \\
\text { per } \\
\text { bunch }\end{array}$ & $\begin{array}{c}\text { Number } \\
\text { of fingers } \\
\text { per } \\
\text { bunch }\end{array}$ & $\begin{array}{c}\text { Finger } \\
\text { length } \\
(\mathrm{cm})\end{array}$ & $\begin{array}{c}\text { Finger } \\
\text { circumference } \\
(\mathrm{cm})\end{array}$ & $\begin{array}{c}\text { Finger } \\
\text { weight } \\
\text { (g) }\end{array}$ & $\begin{array}{l}\text { Yield } \\
\text { (t/ha) }\end{array}$ \\
\hline Champa & 10.76 & 79.50 & 80.73 & 10.00 & 141.42 & 13.40 & 9.47 & 47.74 & 23.54 \\
\hline Budubale & 12.26 & 73.50 & 66.81 & 7.57 & 112.72 & 14.10 & 12.33 & 91.65 & 24.33 \\
\hline BCB-3 & 14.77 & 92.67 & 72.63 & 12.87 & 148.91 & 21.07 & 13.17 & 101.21 & 31.37 \\
\hline H-531 & 9.71 & 76.18 & 72.02 & 6.00 & 75.27 & 14.00 & 12.37 & 98.29 & 19.72 \\
\hline BCB-1 & 11.98 & 74.83 & 67.53 & 8.03 & 130.41 & 19.27 & 13.27 & 86.68 & 25.07 \\
\hline KBS-8 & 11.14 & 79.37 & 71.17 & 8.90 & 116.66 & 20.21 & 14.13 & 97.37 & 22.06 \\
\hline Bantal & 12.08 & 78.47 & 68.63 & 9.60 & 92.07 & 19.08 & 16.90 & 131.27 & 23.35 \\
\hline BCB-2 & 16.52 & 82.27 & 70.97 & 12.80 & 125.05 & 19.53 & 14.20 & 137.48 & 35.18 \\
\hline KovurBontha & 9.47 & 70.60 & 61.37 & 7.00 & 83.20 & 21.43 & 16.27 & 89.28 & 20.79 \\
\hline ManjeriNendran II & 12.35 & 63.63 & 60.10 & 5.83 & 58.24 & 26.10 & 13.03 & 141.70 & 26.72 \\
\hline NRCB-8 & 15.14 & 84.87 & 74.43 & 10.03 & 146.08 & 21.83 & 11.33 & 104.91 & 30.53 \\
\hline $\operatorname{SEm}( \pm)$ & 0.33 & 1.29 & 0.55 & 0.17 & 1.06 & 0.51 & 0.18 & 0.88 & 0.60 \\
\hline CD5\% & 0.96 & 3.81 & 1.62 & 0.51 & 3.14 & 1.49 & 0.53 & 2.59 & 1.77 \\
\hline
\end{tabular}


Highest finger length was recorded in ManjeriNendran II $(26.10 \mathrm{~cm})$ which was better than rest whereas lowest finger length was observed in Champa $(13.40 \mathrm{~cm})$.A range of $9.47 \mathrm{~cm}$ to $16.90 \mathrm{~cm}$ was noticed in case of finger circumference (Table 1).

Bantal recorded the maximum i.e. $16.90 \mathrm{~cm}$ whereas Champa recorded the minimum $(9.47$ $\mathrm{cm})$.A significant range of variation of 47.74 to $141.70 \mathrm{~g}$ was noticed in case of finger weight (Table 1). Maximum finger weight was observed in ManjeriNendran II (141.70 g) which was at par with BCB-2 (137.48 g). However minimum fruit weight was observed in Champa (47.74 g).

It was revealed from the results on yield/ha of the experiment (Table 1) that the clones exhibited significant differences among them. The highest yield was recorded under the clone BCB-3 (31.37 t/ha) among dessert banana whereas highest yield in culinary banana was observed in BCB-2 (35.18 t/ha).

The yield of the plant is the most important trait for the purpose of cultivation. The duration also pays a vital role in the crop cultivation along-with vegetative growth parameters. It was observed in the experiment that BCB-3 took 322.33 days from planting to harvest which was more as compared to other varieties H-531 (303 days), KBS-8 (317.67 days) and BCB-1 (318.33 days). BCB-3 has superseded to these varieties with respect to yield. Hence it may be attributed that as BCB3 took more number of days to mature it might have drawn more water and nutrients from the soil, ultimately being able to produce more yield.
Further, the root system (not studied) might have also played a major role in enhancing the yield. Further, the lack of disease infestation in BCB-3 might have boosted yield as the normal physiological processes might have been completed successfully.

Similarly among the culinary types BCB-2 out yielded the other clones of this type which may be attributed to similar causes as that given for BCB-3 under dessert types.

Overall BCB-3 and BCB-2 have been found to be superior under the coastal zone conditions in the present experiment. As the coastal zone is highly prone to diseases like Panama wilt and Sigatoka leaf spot diseases due to the presence of high humidity, these clones may be tried in multi-location and then may be recommended for cultivation. This is in agreement with the observations of earlier research workers (Rosamma and Namboodiri, 1999; Uma et al., 2000; Sheela and Nair, 2001).

\section{References}

Rosamma CA and Namboodiri K. 1999. Genetic analysis of yield in banana, Agriculture Research Journal of Kerala, 28: 1-8.

Uma S, Dayarani M, Singh HP, Shyam B and Sathiamoorthy S. 2000. Studies on genetic variability in Banana Silk sub group AAB, Indian Journal Horticulture, 57(2): 106-109.

Sheela VL and Nair SR. 2001. Growth flowering and yield potential of tissue culture banana cv. Nendran, Journal of Tropical Agriculture, 39: 1-4.

\section{How to cite this article:}

Kiran Patnaik and Pratichee Mohapatra. 2019. Evaluation of Elite Clones of Banana on Yield and Yield Attributing Parameters in Coastal Zones of Odisha. Int.J.Curr.Microbiol.App.Sci. 8(12): 960-963. doi: https://doi.org/10.20546/ijcmas.2019.812.123 